\title{
PENGGUNAAN TEKNIK THINK-PAIR-SHARE UNTUK PENINGKATAN KOMPETENSI FISIKA
}

\section{THE USE OF THINK-PAIR-SHARE TECHNIQUES FOR IMPROVING THE COMPETENCE OF PHYSICS}

\author{
A Sesrita1a \\ ${ }^{1}$ Program Studi Pendidikan Guru Sekolah Dasar, Fakultas Keguruan dan Ilmu Pendidikan, \\ Universitas Djuanda Bogor, Jl Tol Ciawi No. 1 Kotak Pos 35 Ciawi Bogor 16720 \\ a Korespondensi: Afridha Sesrita, Email: afridha.sesrita@unida.ac.id \\ (Diterima: 28-08-2017; Ditelaah: 29-08-2017; Disetujui: 15-10-2017)
}

\begin{abstract}
The purpose of the research is to create a think-pair-share technic tool and it is expected that its development results are stated to be practical, valid and have effective and feasible use during learning. This research uses research and development method (R \& D) 4D model that is define, design, develop and disseminate. The final result is the implementation plan of learning, syllabus, assessment and student worksheet that is declared valid, effective and also practical on affective, psychomotor, and cognitive aspects by some experts in their field (validator). The use of think-pair-share tech device is able to improve students' competence in physics subject both on affective, psychomotor and cognitive aspects.
\end{abstract}

Keywords: think-pair-share, physics competence, research and development

\begin{abstract}
ABSTRAK
Tujuan pelaksanaan penelitian ini yaitu membuat perangkat berteknik think-pair-share dan hasil pengembangannya dinyatakan telah praktis, valid dan memiliki keefektifan serta layak dipakai selama pembelajaran. Penelitian ini menggunakan metode research and development (R\&D) model 4D yakni define, design, develop dan desseminate. Hasil akhir berupa rencana pelaksanaan pembelajaran, silabus, assesmen dan lembar kerja siswa yang dinyatakan valid, efektif dan juga bersifat praktis pada aspek afektif, pskimotor dan kognitif oleh beberapa ahli dibidangnya (validator). Penggunaan perangkat berteknik think-pairshare ini ternyata mampu meningkatkan kompetensi siswa pada mata pelajaran fisika baik pada aspek afektif, psikomotor maupun kognitif.
\end{abstract}

Kata kunci: think-pair-share, kompetensi fisika, penelitian dan pengembangan

Sesrita A. 2017. Penggunaan teknik think-pair-share untuk peningkatan kompetensi fisika. Didaktika Tauhidi Jurnal Pendidikan Guru Sekolah Dasar 4(2): 140-158.

\section{PENDAHULUAN}

Banyak pemanfaatan ilmu ataupun teori fisika sering ditemukan dalam kehidupan dan berkontribusi terhadap kemajuan perkembangan teknologi maupun pengetahuan. Sebaiknya sebagai seorang siswa diperlukan pemahaman konsep terhadap ilmu fisika. Dalam memperoleh pemahaman suatu konsep, tidak hafalan teori saja yang diharapkan, tetapi siswa diajak dalam proses pengalaman memperoleh pembelajaran. Siswa selain itu dibiasakan mengkontruksi konsep agar 
mampu mengaplikasikan ilmu tersebut dikehidupan nyata.

Dalam menemukan konsep sebaiknya guru membuat kelompok belajar siswa supaya saling bekerja sama. Dengan demikian akan menumbuhkan sikap tanggung jawab dan berpartisipasi. Jika pembelajaran fisika dilaksanakan seperti ini, susana belajar menjadi lebih senang, aktif, semangat, termotivasi selama belajar bahkan dapat atau mampu memahami teori fisika sehingga kompetensi tercapai sejalan dengan kurikulum.

Berdasarkan pengamatan peneliti pada SMPN 1 Ciburuy terlihat bahwa pembelajaran di pelajaran fisika sangat terpusat kepada guru (satu arah) yang mana pola pembelajaran hampir disetiap pembelajaran adalah guru selalu ceramah dalam menjelaskan konsep, diikuti contoh soal/penerapan, memberikan latihan dan sejumlah tugas rumah. Pola pembelajaran seperti diatas tergolong dalam pembelajaran konvensional. Dengan pola konvensional yang dilaksanakan didalam kelas, siswa menjadi kurang aktif dan hilangnya motivasi belajar. Motivasi siswa kurang muncul yang berakibat pada kurang mampunya siswa mengungkapkan gagasan mereka. Pengamatan dilakukan juga pada perangkat yang disiapkan guru seperti RPP, silabus, diktat belajar, asesmen (penilaian) dan LKS.

Pada RPP belum dijabarkan dengan jelas capaian pembelajaran baik untuk setiap aspek penilaian. Termasuk belum tersedianya LKS serta diktat belajar fisika yang mengakomodasi keperluan dan kebutuhan saat belajar serta menunjang terlaksananya pembelajaran dengan baik. Sama halnya penilaian siswa masih terbatas pada kompetensi aspek kognitif saja. Padahal penilaian yang diharapkan kurikulum adalah penilaian kelas dengan mencakup proses selama kegiatan hasil sehingga kompetensi siswa tercapai maksimal selain itu memiliki kecakapan hidup untuk bekal hidupnya nanti.

Guru dikatakan profesional bila mampu memilih pendekatan, model, metode, strategi atau teknik yang tepat dalam pembelajaran. Guru selaku seorang pendidik seharusnya bisa dan mampu memotivasi, mengaktifkan, membimbing siswa serta mengajak untuk berpartisipasi secara aktif sehingga kompetensi siswa (kecakapan hidup) dapat berkembang. Selain itu, seyogyanya guru telah menyiapkan perangkat yang diperlukan saat pembelajaran agar mampu mengakomodasi kebutuhan siswa seperti merancang RPP, menyediakan LKS dan diktat belajar sesuai model maupun pendekatan serta pemilihan metode bersesuaian akan materi dan karakter siswa.

Keinginan ini nampaknya sejalan dengan harapan yang dituangkan oleh PeraturanPemerintah No 19 pada tahun 2005 dan Peraturan-Menteri-Pendidikan-Nasional No 41 di tahun 2007 yang membahas perihal standar-proses dimana mengharapkan seorang guru dapat mengembangkan RPP. Pengembangan RPP tersebut diharapkan terpusat dua arah dan menyenangkan sehingga termotivasi siswa saat belajar. Perangkat pembelajaran berbasis teknik think-pair-share merupakan satu antara solusi dari masalah yang dijabarkan di atas. Teknik ini mengharapkan masing-masing siswa berfikir secara mandiri, bertukar pikiran, berbagi serta mampu menyampaikan ide dan pendapat agar siswa terbiasa berpikir logis, termotivasi dan dapat mengoptimalkan keaktifan serta berperan aktif sehingga tercipta atmosfer pembelajaran kondusif dan menyenangkan. Oleh karena itu, berdasarkan uraian-uraian tersebut, maka sekiranya diperlukan 
pengembangan akan perangkat berbasis teknik Think-Pair-Share.

\section{MATERI DAN METODE}

\section{Materi}

\section{Think-Pair-Share}

Model gotong royong dikenal dengan kooperatif ini menginginkan siswa belajar berinteraksi langsung dengan anggota antar kelompok yang secra akademik berbeda. Pembelajaran kooperatif membiasakan secara tak langsung untuk bekerjasama, menjadi pemimpin, melatih untuk berani berkomunikasi dimulai dari kelompoknya, berani tampil, mengasah kepercayaan dirinya, tidak menang sendiri (egois) dan berdemokrasi. Masing-masing anggota dituntut untuk bekerjasama dan menyampaikan pendapatnya guna pencapaian tujuan kelompok.

Anggota antar kelompok menjadi aktif karena pendapatnya akan dimintai agar tercapai apa saja harapan kelompok. Dengan adanya kontribusi antar anggota maka akan memberikan tempat bagi siswa kemampuan sedang untuk lebih dihargai. Pembelajaran belum berhasil jika masih terdapat anggota dari kelompok belum paham dan mengetahui secara mendalam materi yang dibahas bersama saat itu. Jika keseluruhan anggota memahami materi ataupun konsep yang dipelajari, ini berarti tujuan kelompok sudah tercapai. Setelah dilakukan persentasi didepan kelas, guru akan melakukan pengevaluasian tentang apa yang sudah dipelajari. Kelompok kooperatif bekerjasama pada sebuah kelompok dengan 2 hingga 5 anggota yang sifatnya heterogen secara akademik, suku maupun jenis kelamin. Pengelompokkan antar siswa bertujuan untuk memumbuhkan sikap mau menerima dan bekerjasama dengan berbeda latarbelakang.

Adapun sintaks pembelajaran ini dimodifikasi sesuai pendapat Ibrahim (2000) dan dijabarkan di Tabel 1.

Tabel 1 Sintaks pembelajaran kooperatif

\begin{tabular}{|c|c|}
\hline Fase & Tingkah laku Guru \\
\hline $\begin{array}{l}\text { Fase 1: } \\
\text { Menyampaikan } \\
\text { tujuan yang ada di } \\
\text { indikator dan } \\
\text { memotivasi siswa }\end{array}$ & 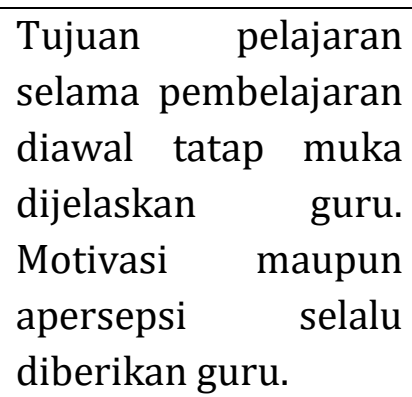 \\
\hline $\begin{array}{l}\text { Fase 2: Menyajikan } \\
\text { informasi }\end{array}$ & $\begin{array}{lr}\text { Dengan } & \text { metode } \\
\text { demonstrasi } & \text { maupun } \\
\text { ceramah, } & \text { guru } \\
\text { menyajikan } & \text { apa-apa } \\
\text { yang akan } & \text { diterima } \\
\text { siswa. }\end{array}$ \\
\hline $\begin{array}{l}\text { Fase 3: } \\
\text { Pengorganisasian } \\
\text { kelompok } \\
\text { belajar }\end{array}$ & $\begin{array}{l}\text { Bersama dengan } \\
\text { siswa, guru membagi } \\
\text { kelompok belajar. }\end{array}$ \\
\hline $\begin{array}{l}\text { Fase 4: } \\
\text { Pembimbingan oleh } \\
\text { guru saat belajar } \\
\text { dalam kelompok }\end{array}$ & $\begin{array}{l}\text { Siswa belajar untuk } \\
\text { menuntaskan } \\
\text { permasalahan } \\
\text { bersama dalam } \\
\text { kelompok dibawah } \\
\text { bimbingan guru. }\end{array}$ \\
\hline Fase 5: Evaluasi & $\begin{array}{l}\text { Pengevaluasian hasil } \\
\text { belajar oleh guru. }\end{array}$ \\
\hline $\begin{array}{l}\text { Fase 6: Pemberiaan } \\
\text { penghargaan }\end{array}$ & $\begin{array}{l}\text { Pemberian reward } \\
\text { atau penghargaan } \\
\text { untuk jawaban } \\
\text { kelompok yang } \\
\text { dirasa benar dalam } \\
\text { menyampaikan } \\
\text { materi. }\end{array}$ \\
\hline
\end{tabular}


Menurut Lufri (2007), ada empat konsep untuk menggambarkan sebuah model pembelajaran antara lain: adanya sintaks, prinsip-prinsip reaksi, sistem sosial, dan sistem pendukung. Pada sintaks atau langkah-langkahnya, ada enam fase aktivitas, diawali dengan penginformasian tujuan dari aktivitas belajar serta motivasi oleh guru kemudian diikuti dengan fase penyajian informasi. Kemudian dilanjutkan pembagian kelompok oleh guru. Pembagian kelompok tersebut berlandaskan pada langkah teknik gotong royong.

Ada empat belas teknik diskusi kelompok, salah satunya teknik diskusi kelompok berpasangan (think-pair-share). Pada teknik ini, kelompok belajar beranggota dua orang. Untuk tahap pembagian kelompok ini, guru dapat membagi kelompok belajar dengan teknik diskusi lainnya selain teknik think-pairshare seperti teknik jigsaw, kepala bernomor, kancing gemerincing, tari bambu dan sebagainya. Fase berikutnya bersama dalam kelompok, guru membahas tugastugas yang diberikan. Fase evaluasi merupakan fase paling akhir pada tahap model ini. Setelah itu, baru guru memberikan reward kepada kelompok maupun perorangan untuk memotivasi siswa secara tidak langsung.

Teknik ini memberi peluang secara mandiri serta kemiliki kemampuan kerjasama antar anggota dalam kelompok. Dengan teknik TPS, suasana semakin kondusif saat belajar, timbul keaktifan karena dituntut berfikir sendiri untuk memecahkan masalah, kritis serta logis. Kelebihan teknik TPS antara lain mengoptimalkan partisipasi siswa. Prosedur dari teknik think-pair-share yaitu sejenak siswa memikirkan dan menjawab berbagai pertanyaan kemudian antar anggota saling membantu.
Pada teknik ini, persoalan diberikan guru lalu beberapa saat siswa diminta think (berfikir) sendiri jawaban pertanyaan tersebut, kemudian pair dengan pasangannya untuk merangkum jawaban. Akhirnya, siswa berbagi (share) jawabanjawaban kepada tiap anggota. Adapun langkah-langkahnya mengadaptasi dari Ibrahim (2000).

\section{Tahap-1 : Think (berfikir)}

Guru memberikan sejumlah permasalahan tentang konsep atau materi pelajaran, lalu sejenak siswa diminta memikirkan jawaban untuk persoalan yang dibahas secara mandiri. Pada tahapan ini, siswa berfikir sejenak (thinking) dan menganalisis permasalahan agar terbiasa untuk berfikir logis serta kritis.

\section{Tahap-2 : Pair (berpasangan)}

Duduk dengan pasangannya, dimana pasangan dapat berupa teman sebangku atau teman lainnya. Dalam kelompok berpasangan ini, siswa belajar mendiskusikan secara bersama perihal persoalan yang disajikan sehingga menimbulkan sikap terbiasa dalam mengungkapkan ide, pendapat atau gagasan, bertukar pikiran, bekerjasama dan mengasah kepercayaan diri. Dalam kelompok ini, antar siswa mampu berinteraksi untuk menyamakan jawaban ataupun ide. Waktu dalam membahas ini sekitar 5 menit.

\section{Tahap-3 : Share (berbagi)}

Tahap dimana guru meminta beberapa kelompok berpasangan untuk berbagi ide didepan kelas. Guru meminta seperempat pasangan bergiliran tampil menyampaikan jawaban menurut pandangan mereka. Kemudian, guru merefleksi dan menyimpulkan serta pemberian reward 
pada pasangan dengan jawaban benar. Terakhir guru mengevaluasi.

Keunggulan kelompok berpasangan dalam pandangan Lie (2002) yaitu meningkatkan partisipasi anggota kelompok. Mempunyai kesempatan lebih dalam mengkontribusikan pendapat masing-masing anggota kelompok. Interaksi lebih mudah. Berdasarkan kutipan yang dijelaskan diatas, teknik think-pair-share (berpasangan) dapat meningkatkan dan mengoptimalkan partisipasi memunculkan keaktifan, fikiran kritis tiap siswa. Kontribusi (argumentasi) anggota kepada kelompoknya diperlukan agar tercapai tujuan kelompok.

\section{Perangkat Pembelajaran}

Dalam perencanaan pembelajaran, tiap-tiap satuan pada dunia pendidikan diwajibkan untuk menyusun perangkat untuk digunakan sebagai pedoman dalam pelaksanaan pembelajaran. Perangkat selama pembelajaran merupakan segala macam alat maupun bahan yang berguna oleh guru untuk melakukan proses pembelajaran. Perangkat pada penelitian ini yakni RPP, silabus, diktat belajar, asesmen (penilaian) dan LKS yang mau dikembangkan. Diktat belajar merupakan bahan yang mampu membantu guru melaksanakan berbagai kegiatan dalam pembelajaran dapat berupa bahan tak tertulis maupun yang tertulis.

Kemanfaatan RPP dalam pelaksanaaan pembelajaran sangat membantu guru. Petunjuk dalam RRP dijelaskan secara rinci per pertemuan, penjelasan perihal kompetensi maupun tujuan yang akan dikuasai siswa, lingkup materi apa saja yang akan dijelaskan guru, media, asesmen (penilaian 0 dan evaluasi yang akan digunakan. Komponen penyusun RPP antara lain yaitu (a) indentitas mencakup nama sekolah, mata pelajaran, kelas/semester, pokok bahasan, alokasi waktu, (b) SK, (c) $\mathrm{KD}$, (d) indikator, (e) tujuan pembelajaran, (f) materi pembelajaran, (g) metode pembelajaran, (h) kegiatan pembelajaran, (i) penilaian hasil belajar, (j) sumber belajar.

Silabus adalah kumpulan rencana dalam satu mata pelajaran atau tema tertentu untuk satu semester, penjabaran dari SK, KD dan materi pokok, kegiatan saat pembelajaran serta indikator pencapaian yang digunakan untuk penilaian. Disimpulkan bahwa silabus merupakan seperangkat kegiatan atau rencana mengenai pembelajaran, pengelolaan didalam kelas dan penilaian (asesmen) hasil belajar. Adapun komponen yang perlu terdapat dalam silabus adalah (a) identitas mencakup nama sekolah, mata pelajaran, kelas/semester, alokasi waktu (b) kompetensi mencakup SK dan KD, (c) indikator, (d) materi pelajaran, (e) kegiatan pembelajaran, (f) penialain, (g) alokasi waktu, dan (h) sumber belajar.

Diktat belajar merupakan kumpulan pengetahuan (konsep, fakta, prinsip, prosedur), sikap maupun keterampilan yang dipelajari oleh siswa dalam mencapai standar kompetensi yang itentukan. Diktat belajar dapat didefenisikan sebagai isi pembelajaran yang nantinya akan disampaikan guru kepada siswa didalam kelas. Keberadaan diktat belajar ini sangat efektif dan menghemat waktu dalam belajar. Dengan demikian guru memiliki waktu secara intens membimbing dalam belajar.Prinsip-prinsip yang perlu diperhatikan dalam menyusun diktat belajar, yaitu (1) relevansi, (2) konsistensi dan (3) kecukupan. Prinsip relevansi yaitu memperhatikan keterkaitan materi yang disusun selama belajar dengan tujuan dan capaian SK dan KD. Prinsip konsistensi yang dimaksud dimana adanya keteraturan 
antara capaian KD yang semestinya dikuasai siswa dengan bahan atau materi yang disusun. Prinsip kecukupan berarti materi yang disusun cukup memenuhi kebutuhan atau telah memadai sehingga siswa terbantu dalam penguasaan $\mathrm{KD}$.

LKS berisi lembaran-lembaran tugas siswa. LKS salah satu alat bantu media pembelajaran. Dengan LKS sebagai media pembelajaran, maka guru dapat mengecek sejauhmana kemampuan siswa memahami suatu konsep yang mereka telah pelajari.

Adapun manfaat penggunaan sebuah LKS selama pembelajaran yaitu (1) mampu mengaktifkan siswa, (2) membantu siswa mengembangkan konsep, (3) melatih dan membiasakan siswa mengembangkan keterampilan proses, (4) sebagai pedoman guru dan siswa selama pembelajaran, (5) membantu siswa memperoleh penjelasan materi saat kegiatan belajar, (6) membantu menambah informasi siswa tentang konsep materi secara sistematis (Suyitno, 2006). Asesmen adalah suatu kegiatan pengumpulan informasi terkait variabel penting sebagai bahan dalam pengambilan keputusan guru dalam perbaikan selama proses serta hasil belajar siswa. Variabel penting disini setidaknya berisikan keterampilan, pengetahuan, sikap dan pemahaman siswa yang mana guru mendapatkan informasi tersebut dari berbagai metode baik secar formal maupun informal. Asesmen juga diartikan sebagai suatu proses kegiatan guru memberikan informasi secara menyeluruh perihal proses maupun hasil pencapaian siswa selama belajar.

Sistem asesmen tuntutan kurikulum yaitu Asessmen Berbasis Kelas ABK yang secara terpadu dilaksanakan baik di kelas maupun di luar kelas, yang mana terintegrasi pada pembelajaran atau diwaktu khusus. ABK tidak sekedar berupa tes atau pengukuran yang selama ini lazim digunakan untuk mengevaluasi kemajuan belajar siswa. ABK dilaksanakan melalui suatu proses secara bertahap dimulai dari perencanaan, kemudian penyusunan penilaian, lalu megumpulkan informasi lewat sejumlah bukti terhadap capaian hasil pembelajaran siswa, terakhir tahap pengolahan informasi.

\section{Kompetensi Fisika}

Kompetensi (competency) fisika siswa ialah tingkat pemahaman terhadap pelajaran fisika seorang siswa. Makna dari memiliki kompetensi disini mengandung arti bahwa siswa mampu memaknai, memahami dan memanfaatkan ilmu yang diperoleh. Dengan kata lain, ilmu yang dimiliki mampu mengembangkan kecakapan dan keterampilan hidup. Inilah hakikat sebuah pembelajaran, dimana siswa dibekali ilmu agar mampu hidup secara mandiri tanpa bergantung pada bantuan orang lain. Dengan demikian belajar tidak cukup hanya sampai mengetahui dan memahami.

Adapun kompetensi selama dan sesudah proses pembelajaran yang harus ada pada siswa adalah kemampuan bidang kognitif (penalaran, pemahaman, analisis, observasi, aplikasi, identifikasi, investigasi, komunikasi, eksplorasi, koneksi, inkuiri, hipotesis, kreativitas, konjektur, generalisasi, pemecahan masalah), kemampuan bidang afektif (pengendalian impulsi, pengendalian kesadaran diri, empati, pengendalian suasana hati, motivasi dan aktivitas positif), dan kemampuan bidang psikomotorik berupa sosialisasi serta kepribadian akan kemampuan presentasi, berargumentasi dan berprilaku. Menurut Depdiknas (2004) telah menetapkan bahwa kompetensi siswa diperoleh dengan baik jika ranah taksonomi Bloom dapat teraplikasi dengan tepat. 
Teori Validitas, Efektivitas dan Praktikalitas Perangkat

Uji validitas dilakukan agar mengetahui kesahihan instrumen yang digunakan. Dalam menyusun instrumen penelitian perlu mempertimbangkan apa saja yang nantinya mau diukur, apakah ada relevansinya data yang diperoleh dengan karakteristik sifat yang diharapkan, serta sejauh mana gambaran skor dari karakteristik yang diukur tersebut. Validitas sebuah tes mengandung empat komponen yaitu validitas isi, validitas bahasa, validitas konstruk, dan validitas kriteria. Instrumen dapat dinyatakan berkategori valid bila instrumen tersebut mampu menginterpretasikan apa yang diharapkan serta mampu mengungkapkan variabel secara tepat.

Kata effective dalam bahasa inggris berarti tepat, berhasil, atau manjur. Efektivitas menunjukkan tingkatan keberhasilan suatu pencapaian tujuan. Jadi, suatu upaya dinyatakan bersifat efektif bila upaya tersebut mampu mencapai tujuannya.

Dalam KBBI (2002) kata efektif diartikan sebagai "adanya efek baik pengaruh ataupun akibatnya" atau "berhasil dalam bentuk usaha dan tindakan)" kemudian kata efektivitas didefenisikan sebagi "keadaan berkesan atau berpengaruh" atau " suatu keberhasilan (usaha, tindakan)". Menurut Mulyasa, suatu pembelajaran dapat dikatakan efektif apabila seluruh siswa dilibatkan secara aktif baik mental, fisik, maupun sosial. Dari defenisi efektivitas ini ditarik simpulan bahwa efektivitas merupakan ukuran yang mampu menyatakan seberapa kualitas, kuantitas dan waktu yang diperoleh dalam mencapainya. Produk bersifat efektif bila mampu memberikan hasil sesuai dan sejalan dengan tujuan yang ditetapkan pengembang.

Menurut KBBI (2008), praktikalitas berarti praktis, berarti senang atau mudah penggunaannya. Kepraktisan yang ditujukan pada penelitian ini yaitu kepraktisan bidang pendidikan (produk seperti instrumen, diktat belajar, maupun lainnya). Praktikalitas berhubungan dengan kemudahan yang diperoleh siswa saat menggunakan instrumen, diktat belajar, ataupun produk sebagainya. Secara empiris, kepraktisan diperoleh melalui uji pengembangan terhadap keterlaksanaan proses pembelajaran dengan penggunaan diktat belajar.

Dalam penelitian pengembangan model yang dikembangkan dikatakan praktis jika para ahlidan praktisi menyebutkan secara teoretis tentang model yang diterapkan selam ini serta tingkat keterlaksanaannya model termasuk kategori "baik". Suatu produk dikatakan praktis bila bersifat usable atau dapat digunakan.

\section{Metode}

Jenis dari penelitian adalah $R \& D$ dengan model pengembangan 4-D. Namun penelitian ini melakukan hanya sampai tahap develop dikarenakan terbatasnya kemampuan peneliti. Adapun pengembangan perangkat yang peneliti buat diantaranya RPP, LKS, silabus, diktat belajar dan asesmen. Prosedur penelitian diawali pada kegiatan pengembangan perangkat pembelajaran, kemudian hasil pengembangan dilakukan penguji cobaan. Implementasi di kelas uji coba dilaksanakan di SMPN 1 Ciburuy pada tahun ajaran 20162017. Pelaksanaan uji coba mengimplementasikan rancangan one group pretest postest design dengan pola: 


\section{$\mathrm{O}_{1} \mathrm{XO}_{2}$}

Keterangan: $\mathrm{O}_{1}=\mathrm{Uji}$ awal untuk mengetahui pengetahuan awal siswa sebelum belajar dimulai; $\mathrm{X}=$ perangkat berbasis teknik think-pair-share; $\mathrm{O}_{2}=\mathrm{uji}$ akhir untuk mengetahui penguasaan materi setelah pembelajaran.

Alur penelitian dapat dilihat pada Gambar 1.

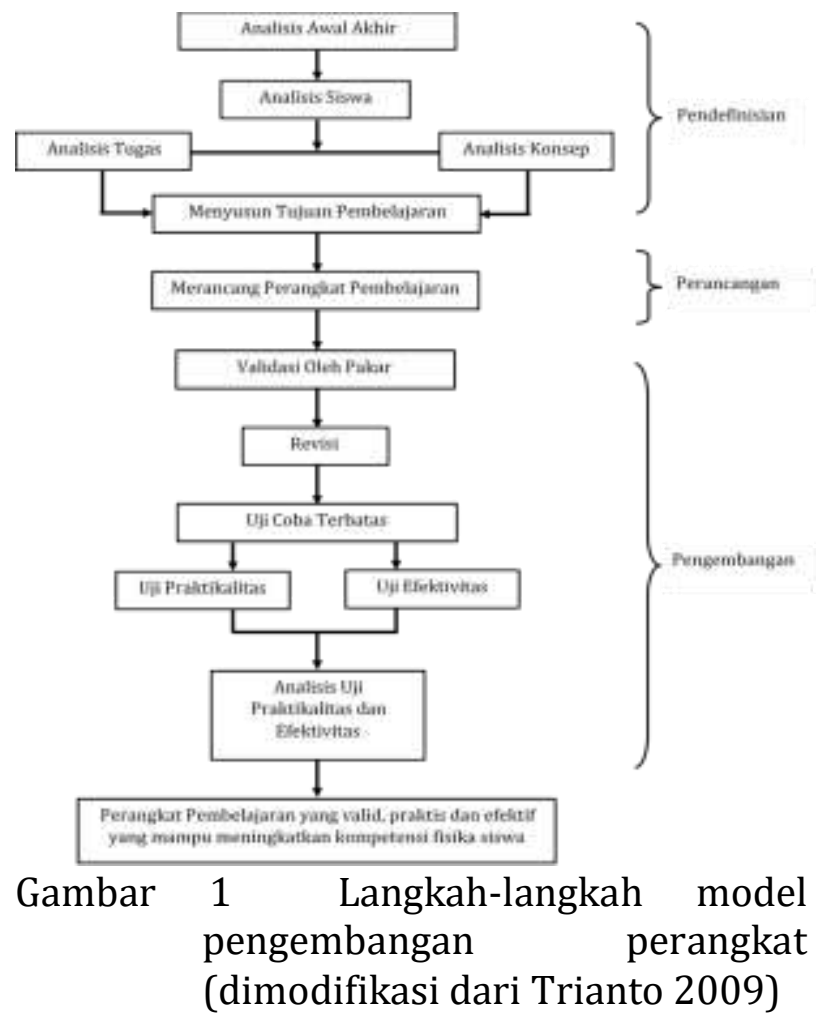

\section{HASIL DAN PEMBAHASAN}

\section{Hasil}

\section{Hasil Tahap Pendefinisian}

\section{Hasil Analisis Awal dan Akhir}

Penganalisisan ini bertujuan untuk menentukan permasalahan utama yang lagi dihadapi oleh guru selama pembelajaran berlangsung. Dalam kegiatan ini juga diperlukan analisis pada kurikulum. Analisis kurikulum ini ditujukan agar mengetahui tujuan selama berlangsungnya pembelajaran dan KD yang diharapkan. Silabus yang dikembangkan seharusnya telah sesuai dengan BSNP (Badan Standar Nasional Pendidikan) tahun 2007.
Tahap analisis kurikulum yang dilakukan dengan menjabarkan SK (standar kompetensi) serta KD (kompetensi dasar) kedalam materi pokok pembelajaran, indikator pencapaian masing-masing kompetensi serta kegiatan (skenario) pembelajaran. Penjabaran standar kompetensi, kompetensi dasar dan indikator dimateri bertujuan untuk menyusun, merancang sebuah rencana pelaksanaan pembelajaran, diktat belajar, LKS dan penilaian. Uraian mengenai indikator, tujuan pembelajaran beserta kegiatan pembelajaran dijelaskan pada tiaptiap pertemuan. RPP dibuat dengan alokasi 90 menit untuk setiap kali pertemuan. Dalam menganalisis RPP bagian yang perlu diperhatikan yaitu pada kegiatan (skenario) pembelajaran dimana skenario ini dirancang mampu melibatkan siswa dalam sebuah pengalaman belajar sehingga tercipta nuansa belajar gembira serta terjadi interaksi dua arah seperti siswa dengan guru, siswa dengan siswa, siswa dengan lingkungan belajar.

Pengalaman belajar dilaksanakan dengan teori belajar yang relevan dengan teknik think-pair-share dengan tujuan siswa dapat berfikir secara mandiri dalam memecahkan masalah, mampu berfikir secara logis maupun kritis, termotivasi serta dapat mengoptimalkan partisipasi belajar dalam bimbingan guru dengan bantuan media pembelajaran seperti diktat belajar dan LKS. Dengan demikian, potensi kemampuan (kompetensi) siswa dapat tercapai sesuai yang diharapkan dalam kurikulum baik kemampuan kognitif, afektif maupun psikomotor. Penyesuaian antara indikator suatu kompetensi dengan perangkat yang dikembangkan harus memperhatikan karakteristik peserta didik, karakteristik materi pelajaran, potensi sekolah yang semua diformulasikan kebentuk sebuah 
kata kerja operasional. Dari hasil analisis kurikulum, maka dikembangkanlah perangkat pembelajaran berteknik thinkpair-share.

\section{Hasil Analisis Siswa}

Analisis dilakukan untuk menelaah karakteristik siswa yang meliputi latar sosial dan ekonomi orang tua siswa siswa dan kemampuan akademik. Data-data siswa peneliti peroleh dari wakil kesiswaan berupa jumlah siswa dan data pekerjaan tiap orang tua siswa. Data yang peneliti peroleh, jumlah siswa sebanyak 165 orang siswa dengan rincian 73 orang berjenis kelamin laki-laki, 92 orang siswa perempuan. Latar belakang pekerjaan dari orang tua pun sangat bervariasi. Ada yang bertani sebanyak 45\%, buruh (tani\&bangunan) sebanyak 40\%, PNS sebanyak $10 \%$, dan lain-lain sebanyak 5\%. Terlihat bahwa status sosial dan ekonomi dari orang tua dikategori menengah ke bawah. Ini berarti lingkungan sangat mempengaruhi motivasi dan keinginan pergi sekolah dan belajar. Dengan kondisi lingkungan keluarga yang minim dengan pendidikan, membuat siswa-siswi kurang termotivasi dan lemahnya tekad untuk bersekolah. Tujuan terpenting dari orang tua kebanyakan hanya agar anak-anak mereka dapat menamatkan sekolah dengan harapan memperoleh ijazah yang bisa membantu anak-anak mereka memperoleh ijazah pekerjaan, apalagi daerah sekitar domisili banyak ditemukan pabrik.

Selain data mengenai jumlah siswa dan jenis kerja dari orang tua siswa, peneliti juga meminta data nilai rata-rata rapor tiga semester sebelumnya pada mapel fisika.Data ini sengaja peneliti minta dengan tujuan yaitu untuk melihat sejauhmana pemahaman konsep dan kemauan belajar fisika siswa. Distribusi nilai rata-rata rapor semester pada tiga semester sebelumnya, terlihat pada Tabel 2 .

Tabel 2 Nilai rata-rata semester siswa

\begin{tabular}{lccc}
\hline Kelas & $\begin{array}{c}\text { Rata-rata } \\
\text { NR Fisika } \\
\text { Semester } \\
\text { Ganjil } \\
\end{array}$ & $\begin{array}{c}\text { Rata-rata } \\
\text { NR Fisika } \\
\text { Semester } \\
\text { Genap }\end{array}$ & $\begin{array}{c}\text { Rata-rata } \\
\text { NR Fisika } \\
\text { Sememster } \\
\text { Ganjil }\end{array}$ \\
\hline IX $_{1}$ & 54,77 & 2015 & 2016 \\
IX $_{2}$ & 53,46 & 53,86 & 64,94 \\
IX $_{3}$ & 53,65 & 54,22 & 63,43 \\
\hline
\end{tabular}

Kemampuan akademik siswa pun dapat dikategorikan berkemampuan rendah hingga menengah. Untuk itu, guru perlu memilih model, metode, strategi atau teknik agar mampu menumbuhkan semangat dan merangsang motivasi, keaktifan, partisipasi, kemandirian sehingga siswa dapat memahami materi secara baik. Selain itu, guru perlu menyediakan perangkat sehingga mampu mengakomodasi kebutuhan siswa.

Perangkat pembelajaran berbasis thinkpair-share dapat menjadi solusi untuk kondisi siswa yang kurang termotivasi, kurang terlibat dalam pengalaman belajar, kurang bisa mengkomunikasikan gagasannya, tidak terbiasa dalam menemukan konsep, tidak mandiri serta tidak terbiasa mencarikan solusi atas permasalahan materi pelajaran.

\section{Hasil Analisis Konsep}

Hasil analisis konsep dalam materi kalor yang diberikan bertujuan untuk mengidentisifikasi konsep-konsep utama dan menyusun secara sistematis sesuai urutan penyajiannya dengan acuan SK (standar kompetensi) dan KD (kompetensi dasar) sesuai silabus. Hasil dari analisis konsep ini, peneliti sajikan dalam bentuk peta konsep. 


\section{Hasil Analisis Tugas}

Analisis dilakukan untuk menentukan indikator apa saja yang dicapai dan tujuan selama pembelajaran dengan melakukan analisis SK (standar kompetensi) dan KD (kompetensi dasar). Berdasarkan analisis SK dan KD serta analisis konsep dimateri kalor, maka dapat dianalisis tugas atau keterampilan yang diperoleh setelah siswa mempelajari pokok bahasan ini adalah sebagai berikut. Menentukan persamaan suhu pada berbagai skala termometer. Menentukan pemuaian yang terjadi di zat cair, padat dan gas. Menerapkan asas Black. Menganalisis proses perubahan wujud masing-masing zat. Menerapkan konsep perpindahan kalor.

\section{Perumusan Tujuan selama Pembelajaran}

Hasil analisis dilakukan untuk mengkonversi hasil dari analisis tugas dan konsep menjadi tujuan pembelajaran khusus. Tujuan ini selanjutnya menjadi landasan dalam penyusunan tes, pemilihan media dan pemilihan metode. Hasil analisis perumusan ini dijabarkan pada tabel 3.

Tabel 3 Hasil perumusan tujuan khusus pembelajaran

\begin{tabular}{|c|c|c|}
\hline Kompetensi Dasar & Indikator & Tujuan Pembelajaran khusus \\
\hline \multirow{12}{*}{$\begin{array}{l}\text { Menganalis } \\
\text { pengaruh dari } \\
\text { kalor terhadap } \\
\text { suatu zat. }\end{array}$} & Pertemuan 1 (2x45") & Dengan bimbingan guru siswa dapat: \\
\hline & 1. Mendeskripsikan & 1. Mendefenisikan pengertian suhu. \\
\hline & $\begin{array}{l}\text { pengertian suhu. } \\
\text { 2. } \text { Mengidentifikasi }\end{array}$ & $\begin{array}{l}\text { 2. Menyebutkan macam dan jenis } \\
\text { termometer. }\end{array}$ \\
\hline & $\begin{array}{l}\text { jenis-jenis } \\
\text { termometer. }\end{array}$ & $\begin{array}{l}\text { 3. Menyatakan persamaan suhu pada } \\
\text { berbagai skala termometer. }\end{array}$ \\
\hline & $\begin{array}{l}\text { 3. Merumuskan } \\
\text { persamaan suhu } \\
\text { pada berbagai skala } \\
\text { termometer. }\end{array}$ & $\begin{array}{l}\text { 4. Mengkonversi persamaan suhu pada } \\
\text { berbagai skala termometer. }\end{array}$ \\
\hline & Pertemuan $2\left(2 \times 45^{\prime \prime}\right)$ & Dengan bimbingan guru, siswa dapat \\
\hline & $\begin{array}{l}\text { 1. Menganalisis } \\
\text { faktor-faktor yang }\end{array}$ & $\begin{array}{l}\text { 1. Menyebutkan faktor-faktor yang } \\
\text { mempengaruhi pemuaian }\end{array}$ \\
\hline & $\begin{array}{l}\text { berpengaruh } \\
\text { terhadap besarnya }\end{array}$ & $\begin{array}{l}\text { 2. Menyelidiki pemuaian zat cair, padat } \\
\text { dan gas. }\end{array}$ \\
\hline & pemuaian suatu zat. & 3. Menjelaskan peristiwa anomali air. \\
\hline & $\begin{array}{l}\text { 2. Menyelidiki proses } \\
\text { memuainya zat cair, } \\
\text { padat dan gas. }\end{array}$ & $\begin{array}{l}\text { 4. Merumuskan koefisien muai panjang, } \\
\text { koefisien muai luas dan koefisien } \\
\text { muai volume. }\end{array}$ \\
\hline & $\begin{array}{l}\text { 3. Menyebutkan } \\
\text { contoh peristiwa } \\
\text { pemuaian yang }\end{array}$ & $\begin{array}{l}\text { 5. Menyelesaikan } \\
\text { mengaplikasikan } \\
\text { pemuaian zat. }\end{array}$ \\
\hline & $\begin{array}{l}\text { sering ditemui } \\
\text { sehari-hari. }\end{array}$ & $\begin{array}{l}\text { 6. Menyebutkan contoh peristiwa } \\
\text { pemuaian yang terjadi disekitar } \\
\text { kehidupan. }\end{array}$ \\
\hline
\end{tabular}

\section{Hasil Tahap Perancangan}

Tahap perancangan dilakukan untuk menyiapkan suatu prototipe atau model dari sebuah perangkat pembelajaran berteknik think-pair-share yang dibuat peneliti. Adapun perangkat yang dikembangkan yakni berupa RPP, silabus, assesmen dan LKS. Beberapa tahap dalam proses perancangan perangkat 
pembelajaran yaitu pertama adalah perancangan silabus. Silabus yang dirancang hanya pada satu materi saja yaitu materi kalor SK 1.4 dengan lima kali pertemuan, berisi identitas mapel, SK dan KD, indikator, materi dan kegiatan pembelajaran, alokasi waktu, sumber belajar dan penilaian. Pengembangan silabus berdasarkan panduan penyusunan KTSP. Indikator, kegiatan belajar serta penilaian yang terdapat di silabus ini mengarah dan berorientasi teknik think-pair-share.

Perancangan selanjutnya adalah pada rencana pelaksanaan pembelajaran RPP yang menggambarkan rencana maupun prosedur pembelajaran serta menjadi pedoman dalam melaksanakan pembelajaran oleh guru. Rancangan RPP disesuaikan dengan langkah-langkah teknik think-pair-share. Dari perancangan RPP dihasilkan lima RPP yang akan disajikan selama 5 kali pertemuan.

Perancangan diktat belajar yang dimaksud yaitu sebuah materi ajar atau diktat belajar yang dibuat sendiri oleh guru dengan harapan agar siswa mampu belajar baik individu apalagi kelompok dengan atau tanpa bimbingan guru. diktat belajar berorientasi teknik think-pair-share dengan materi kalor berisikan enam sub bahasan yaitu bahasan suhu, pemuaian zat, kalor, asas Black, perubahan wujud dan perpindahan kalor.

Perancangan LKS disusun mengacu kepada tujuan pembelajaran dan indikator pencapaian. LKS didesain berorientasi teknik think-pair-share. Tahap Perancangan Perangkat Asesmen merupakan tahapan terakhir. Perangkat asesmen merupakan kumpulan penilaian yang digunakan saat belajar berlangsung. Asesmen yang dikembangkan berbasis kelas dengan memperhatikan karakteristik materi, perangkat yang digunakan serta model yang digunakan. Perangkat asesmen yang dirancang meliputi penilaian lisan, penilaian tulisan, penilaian sikap dan penilaian kinerja.

\section{Hasil Tahap Pengembangan}

\section{Hasil Penilaian Instrumen Validasi}

Tujuan tahapan ini untuk memperoleh perangkat berteknik think-pair-share dilengkapi dengan asessmen berbasis kelas yang bersifat valid dan praktis, sehingga dinyatakan layak untuk dipakai selama pembelajaran. Hasil pada tahapan pengembangan ini yang pertama, Hasil Penilaian Instrumen Validasi bertujuan untuk menguji instrumen berguna dalam mengumpulkan data yang valid, diperlukan validasi terhadap instrumen. Penilaian yang diperoleh dari validator berasal dari dua orang pakar. Hasil pengolahan penilaian instrumen penelitian pengembangan direvisi sebanyak dua kali hingga perangkat dinyatakan telah valid. Perolehan nilai validasi kedua dijabarkan pada tabel 4 dengan rerata persentase nilai kedua validator adalah 99,55\% (sangat baik).

Tabel 4 Hasil lembar penilaian instrumen validasi kedua

\begin{tabular}{|c|c|c|c|c|c|c|c|c|c|c|}
\hline \multirow{2}{*}{ Validator } & \multicolumn{9}{|c|}{ Lembar Penilaian Instrumen Validasi } & \multirow{2}{*}{ Kategori } \\
\hline & \multicolumn{9}{|c|}{ Penilaian (\%) } & \\
\hline 1 & 100 & 100 & 100 & 100 & 100 & 100 & 100 & 100 & 100 & Sangat valid \\
\hline 2 & 92 & 100 & 100 & 100 & 100 & 100 & 100 & 100 & 100 & Sangat valid \\
\hline
\end{tabular}




\section{Hasil Penilaian Validasi}

Validasi Tahap Awal pada lembar validasi dari perangkat yang dikembangkan kemudian dilakukan validasi oleh empat validator yaitu dua orang dari pakar dosen fisika dan dua orang guru fisika. Hasil penilaian validator terhadap lembar validasi tahap awal belum dapat dikategorikan valid, karena lembar validasi yang dibuat perlu

Tabel 5 Revisi perangkat pembelajaran menekankan keterlaksanaannya sesuai teknik think-pair-share, memisahkan penilaian kelayakan isi, konstruk dan bahasa. Kemudian dilakukan revisi berdasarkan pendapat serta saran validator untuk menyempurnakan instrumen penilaian dan perangkat pembelajaran. Saran-saran tersebut dapat dilihat pada tabel 5.

Perangkat Pembelajaran yang Dikembangkan

Sebelum Revisi

Sesudah Revisi

1. Tambahkan pernyataan di lembar validasi RPP tentang keterlaksanaan teknik think-pair-share disetiap aspek indikator pencapaian dan juga pada tujuan pembelajaran.

2. Tambahkan butir pernyataan yang mengaitkan keterlaksanaan think-pair-share pada setiap lembar validasi LKS.

Sudah ditambahkan dalam aspek indikator pencapaian dan juga tujuan pembelajaran sesuai dengan langkah think-pair-share.

Sudah ditambahkan pernyataan di lembar validasi LKS sesuai teknik think-pair-share

3. Pisahkan pernyataan untuk menilai kelayakan isi, kelayakan konstruk dan kelayakan bahasa.

Pernyataan di lembar validasi sudah dipisahkan.

4. Sesuaikan tahap berpikir KD dengan tahap

Sudah disesuaikan. berpikir indikator.

5. RPP sudah bagus, bisa diteruskan pada KD yang Baik. lain.

6. Urutkan antar materi agar saling berkaitan.

Materi sudah diurutkan.

7. Buat untuk lima kali pertemuan.

Sudah dibuat untuk lima kali tatap muka atau pertemuan

8. Jabarkan lagi tujuan pembelajaran. Tujuan pembelajaran lebih dijabarkan.

Lembar penilaian validasi dan perangkat yang sudah direvisi mengikuti saran validator, kemudian divalidasi kembali. Hasil validasi tersebut diuraikan antara lain:

(a) hasil validasi pengembangan silabus dan

(b) hasil validasi RPP. a) Hasil Validasi Pengembangan Silabus

Silabus dikembangkan berdasarkan pada karakteristik siswa dan potensi sekolah. Hasil kevalidan menunjukkan bahwa silabus yang dirancang sudah bisa digunakan tanpa tahapan revisi seperti pada Tabel 6. 
Tabel 6 Hasil validasi pengembangan silabus

\begin{tabular}{|c|c|c|c|c|c|c|c|c|c|}
\hline \multirow{2}{*}{ No } & \multirow{2}{*}{ Standar Penilaian } & \multicolumn{4}{|c|}{ Validator } & \multirow{2}{*}{ Jml } & \multirow{2}{*}{$\begin{array}{l}\text { Skor } \\
\text { mak }\end{array}$} & \multirow{2}{*}{$\%$} & \multirow{2}{*}{$\begin{array}{l}\text { Katego } \\
\text { ri }\end{array}$} \\
\hline & & 1 & 2 & 3 & 4 & & & & \\
\hline 1. & $\begin{array}{l}\text { Kesesuaian KD dengan materi } \\
\text { pembelajaran }\end{array}$ & 4 & 4 & 4 & 4 & 16 & 16 & 100 & $\begin{array}{l}\text { Sangat } \\
\text { valid }\end{array}$ \\
\hline 2. & $\begin{array}{ll}\text { Kesesuaian materi pembelajaran } \\
\text { dengan pengalaman belajar yang } \\
\text { diberikan pada siswa }\end{array}$ & 4 & 3 & 4 & 4 & 15 & 16 & 93 & $\begin{array}{l}\text { Sangat } \\
\text { valid }\end{array}$ \\
\hline 3. & $\begin{array}{l}\text { Kesesuaian indikator dengan } \\
\text { pencapaian kompetensi }\end{array}$ & 4 & 4 & 3 & 4 & 15 & 16 & 93 & $\begin{array}{l}\text { Sangat } \\
\text { valid }\end{array}$ \\
\hline 4. & $\begin{array}{l}\text { Kesesuaian penilaian terhadap } \\
\text { pencapaian kompetensi }\end{array}$ & 4 & 4 & 4 & 4 & 16 & 16 & 100 & $\begin{array}{l}\text { Sangat } \\
\text { valid }\end{array}$ \\
\hline 5. & $\begin{array}{l}\text { Kesesuaian sumber, alat dan bahan } \\
\text { dengan media pembelajaran yang } \\
\text { digunakan adalah LKS berbasis } \\
\text { cooperative tipe TPS }\end{array}$ & 4 & 4 & 4 & 4 & 16 & 16 & 100 & $\begin{array}{l}\text { Sangat } \\
\text { valid }\end{array}$ \\
\hline 6. & $\begin{array}{l}\text { Kecocokan alokasi waktu dengan } \\
\text { materi pembelajaran }\end{array}$ & 4 & 4 & 4 & 4 & 16 & 16 & 100 & $\begin{array}{l}\text { Sangat } \\
\text { valid }\end{array}$ \\
\hline
\end{tabular}

\section{b) Hasil Validasi RPP}

Setelah lembar validasi RPP dan perangkat RPP diperbaiki sesuai dengan saran-saran dari validator, maka dilakukan validasi kembali. Hasil penilaian dari validator menyatakan bahwa rancangan

Tabel 7 Hasil validasi komponen RPP

\begin{tabular}{|c|c|c|c|c|c|c|}
\hline \multirow{2}{*}{ No } & \multirow{2}{*}{ Komponen RPP } & \multicolumn{4}{|c|}{ Validator } & \multirow{2}{*}{ Kategori } \\
\hline & & 1 & 2 & 3 & 4 & \\
\hline 1. & Identitas & Ada & Ada & Ada & Ada & Sangat valid \\
\hline 2 & Standar kompetensi & Ada & Ada & Ada & Ada & Sangat valid \\
\hline 3 & Kompetensi dasar & Ada & Ada & Ada & Ada & Sangat valid \\
\hline 4 & Indikator pencapaian kompetensi & Ada & Ada & Ada & Ada & Sangat valid \\
\hline 5 & Tujuan pembelajaran & Ada & Ada & Ada & Ada & Sangat valid \\
\hline 6 & Materi ajar & Ada & Ada & Ada & Ada & Sangat valid \\
\hline 7 & Alokasi waktu & Ada & Ada & Ada & Ada & Sangat valid \\
\hline 8 & Metode pembelajaran & Ada & Ada & Ada & Ada & Sangat valid \\
\hline 9 & Kegiatan pembelajaran & Ada & Ada & Ada & Ada & Sangat valid \\
\hline 10 & Penilaian hasil belajar & Ada & Ada & Ada & Ada & Sangat valid \\
\hline 11 & Sumber belajar & Ada & Ada & Ada & Ada & Sangat valid \\
\hline
\end{tabular}


Tabel 8 Hasil validasi isi RPP

\begin{tabular}{|c|c|c|c|c|c|c|c|c|c|}
\hline \multirow{2}{*}{ No } & \multirow{2}{*}{ Indikator } & \multicolumn{4}{|c|}{ Nilai validator } & \multirow{3}{*}{$\begin{array}{r}\text { Jml } \\
64\end{array}$} & \multirow{3}{*}{$\begin{array}{r}\begin{array}{l}\text { Skor } \\
\text { mak }\end{array} \\
64\end{array}$} & \multirow{3}{*}{$\begin{array}{l}\% \\
100\end{array}$} & \multirow{3}{*}{$\begin{array}{r}\text { Kategori } \\
\text { Sangat valid }\end{array}$} \\
\hline & & 1 & 2 & 3 & 4 & & & & \\
\hline 1 & $\begin{array}{l}\text { Perumusan indikator } \\
\text { pencapaian kompetensi }\end{array}$ & 16 & 16 & 16 & 16 & & & & \\
\hline 2 & $\begin{array}{l}\text { Perumusan } \\
\text { pembelajaran }\end{array}$ & 12 & 9 & 12 & 12 & 45 & 48 & 93 & Sangat valid \\
\hline 3 & Prinsip pemilihan materi & 20 & 18 & 20 & 20 & 78 & 80 & 97 & Sangat valid \\
\hline 4 & Prinsip pemilihan metode & 12 & 12 & 12 & 12 & 48 & 48 & 100 & Sangat valid \\
\hline 5 & $\begin{array}{l}\text { Penggunaan alat dan } \\
\text { bahan }\end{array}$ & 12 & 12 & 12 & 12 & 48 & 48 & 100 & Sangat valid \\
\hline 6 & $\begin{array}{l}\text { Penggunaan } \\
\text { belajar }\end{array}$ & 8 & 8 & 8 & 8 & 32 & 32 & 100 & Sangat valid \\
\hline 7 & $\begin{array}{l}\text { Jenis } \\
\text { pembelajaran. }\end{array}$ & 12 & 11 & 12 & 12 & 47 & 48 & 97 & Sangat valid \\
\hline 8 & $\begin{array}{l}\text { Susunan langkah-langkah } \\
\text { pembelajaran }\end{array}$ & 20 & 20 & 20 & 20 & 80 & 80 & 100 & Sangat valid \\
\hline 9 & $\begin{array}{l}\text { Pilihan cara-cara } \\
\text { memotivasi siswa }\end{array}$ & 8 & 8 & 8 & 8 & 32 & 32 & 100 & Sangat valid \\
\hline 10 & $\begin{array}{l}\text { Pilihan cara-cara } \\
\text { pengorganisasian } \\
\text { agar dapat berpartisipasi } \\
\text { dalam } \\
\text { pembelajaran. }\end{array}$ & 16 & 16 & 16 & 16 & 64 & 64 & 100 & Sangat valid \\
\hline 11 & $\begin{array}{lc}\text { Melaksanakan } & \text { kegiatan } \\
\text { pembelajaran } & \text { sesuai } \\
\text { dengan urutan yang logis }\end{array}$ & 16 & 16 & 16 & 16 & 64 & 64 & 100 & Sangat valid \\
\hline 12 & $\begin{array}{l}\text { Prosedur penilaian } \\
\text { meliputi penilaian awal, } \\
\text { penilaian tengah (proses), } \\
\text { dan penilaian akhir. }\end{array}$ & 8 & 6 & 6 & 8 & 28 & 32 & 87 & Sangat valid \\
\hline 13 & Penggunaan bahasa & 8 & 6 & 8 & 8 & 30 & 32 & 93 & Sangat valid \\
\hline
\end{tabular}

c) Hasil Validasi Diktat Belajar

Validasi dilakukan untuk memperoleh diktat belajar yang valid sehingga layak untuk digunakan untuk belajar. Hasil validasi diktat belajar dijabarkan pada Tabel 9. 
Tabel 9 Hasil validasi diktat belajar

\begin{tabular}{|c|c|c|c|c|c|c|c|c|c|}
\hline \multirow{2}{*}{ No } & \multirow{2}{*}{ Aspek yang dinilai } & \multicolumn{4}{|c|}{ Penilaian validator } & \multirow{2}{*}{ Jml } & \multirow{2}{*}{ Skor mak } & \multirow{2}{*}{$\%$} & \multirow{2}{*}{ Kategori } \\
\hline & & 1 & 2 & 3 & 4 & & & & \\
\hline 1 & Kelayakan isi & 24 & 20 & 24 & 23 & 91 & 96 & 94 & Sangat valid \\
\hline 2 & Kelayakan konstruksi & 72 & 68 & 72 & 72 & 284 & 288 & 98 & Sangat valid \\
\hline \multirow[t]{2}{*}{3} & Komponen & 28 & 22 & 28 & 28 & 106 & 112 & 94 & Sangat valid \\
\hline & Bahasa & & & & & & & & \\
\hline
\end{tabular}

Berdasarkan tabel 7 di atas hasil validasi diktat belajar untuk aspek kelayakan isi, konstruksi dan komponen bahasa dikategorikan sangat valid. Validasi diktat belajar ini dilakukan untuk mengetahui apakah isi, penyajian dan penggunaan bahasa dari diktat belajar yang dikembangkan sudah sesuai. d) Hasil validasi LKS

Validasi LKS dilakukan untuk mengetahui apakah isi, penyajian dan komponen bahasa dari LKS yang dikembangkan sudah bagus dan layak digunakan dalam proses pembelajaran. Hasil penilaian lembar validasi LKS setelah direvisi, diuraikan pada Tabel 10.

Tabel 10 Hasil validasi lembar kegiatan siswa

\begin{tabular}{llllllrrrr}
\hline \multirow{2}{*}{ No } & \multirow{2}{*}{ Aspek yang dinilai } & \multicolumn{9}{c}{ Penilaian validator } & \multicolumn{3}{c}{ Skor } \\
\cline { 3 - 6 } & & 1 & 2 & 3 & 4 & & maks & Kategori \\
\hline 1 & Kelayakan isi & 24 & 24 & 24 & 24 & 96 & 96 & 100 & Sangat valid \\
2 & Kelayakan konstruksi & 42 & 38 & 42 & 41 & 163 & 168 & 97 & Sangat valid \\
3 & Komponen bahasa & 24 & 20 & 24 & 22 & 90 & 96 & 93 & Sangat valid \\
\hline
\end{tabular}

Berdasarkan Tabel 8, dapat disimpulkan bahwa LKS yang dirancang sudah layak untuk digunakan dalam proses pembelajaran karena nilai dari validasi LKS menunjukkan kategori sangat valid.

e) Hasil Validasi Asesmen

Perangkat asesmen dirancang sesuai dengan model pembelajaran yang digunakan. Setelah perangkat asesmen dan lembar validasi asesmen dirancang, maka dilakukan validasi untuk mengukur kevalidan dari perangkat asesmen yang dirancang oleh validator. Hasil validasi perangkat asesmen diuraikan pada Tabel 11.

Berdasarkan hasil penilaian pada tabel 9, semua validator menyatakan sangat setuju dengan pernyataan untuk aspek-aspek yang dinilai. Rata-rata persentase penilaian dari keseluruhan validator untuk semua aspek adalah 99\% dengan kategori sangat valid. 
Tabel 11 Hasil validasi asesmen

\begin{tabular}{|c|c|c|c|c|c|c|c|c|c|}
\hline \multirow{2}{*}{ No. } & \multirow{2}{*}{ Aspek yang dinilai } & \multicolumn{4}{|c|}{ Validator } & \multirow{3}{*}{$\begin{array}{c}\text { Jml } \\
16\end{array}$} & \multirow{2}{*}{$\begin{array}{l}\text { Skor } \\
\text { mak }\end{array}$} & \multirow[t]{2}{*}{$\%$} & \multirow[t]{2}{*}{ Kategori } \\
\hline & & 1 & 2 & 3 & 4 & & & & \\
\hline 1 & $\begin{array}{l}\text { Kesuaian penilaian dengan } \\
\text { kompetensi yang ingin dicapai }\end{array}$ & 4 & 4 & 4 & 4 & & 16 & 100 & $\begin{array}{l}\text { Sangat } \\
\text { valid }\end{array}$ \\
\hline 2 & Kejelasan prosedur penilaian & 8 & 8 & 8 & 8 & 32 & 32 & 100 & $\begin{array}{l}\text { Sangat } \\
\text { valid }\end{array}$ \\
\hline 3 & Kelengkapan instrumen & 12 & 12 & 12 & 12 & 48 & 48 & 100 & $\begin{array}{l}\text { Sangat } \\
\text { valid }\end{array}$ \\
\hline 4 & Kualitas instrumen & 12 & 12 & 11 & 12 & 47 & 48 & 98 & $\begin{array}{l}\text { Sangat } \\
\text { valid }\end{array}$ \\
\hline 5 & $\begin{array}{l}\text { Kesesuaian penilaian dengan } \\
\text { karakteristik siswa }\end{array}$ & 4 & 4 & 3 & 4 & 15 & 16 & 99 & $\begin{array}{l}\text { Sangat } \\
\text { valid }\end{array}$ \\
\hline 6 & Keberagaman teknik penilaian & 4 & 4 & 4 & 4 & 16 & 16 & 100 & $\begin{array}{l}\text { Sangat } \\
\text { valid }\end{array}$ \\
\hline
\end{tabular}

\section{Peningkatan Kompetensi Fisika}

Peningkatan kompetensi fisika siswa dapat dilihat dari seluruh penilaian selama proses pembelajaran berlangsung baik penilaian secara individu maupun secara kelompok yang mencakup ranah kognitif, afektif dan psikomotor. Penilaian ranah kognitif dilihat dari penilaian lisan dan tertulis. Penilaian lisan dilakukan selama pembelajaran berlangsung. Penilaian tertulis diambil dari nilai tugas LKS dan tes akhir. Soal tes akhir berupa pilihan ganda sebanyak 30 soal. Soal tes ini sudah diuji cobakan terlebih dahulu pada sekolah lain dan sudah divalidasi, dicari reabilitas, daya beda dan indeks kesukaran soal (peneliti menggunakan program ANATES Pilihan Ganda versi 4.0.9). Soal uji coba terdiri dari 40 soal dan setelah dianalisis terdapat 10 soal yang dibuang. Soal hasil analisis inilah yang dijadikan soal tes akhir pada kelas yang diteliti. Penilaian ranah afektif dilihat dari sikap siswa selama melaksanakan proses pembelajaran, dan penilaian ranah psikomotor dilihat dari kinerja siswa dalam melaksanakan kegiatan pembelajaran. Semua penilaian ini bertujuan untuk melihat keseriusan dan perkembangan kemajuan belajar siswa.

Sebelum dilakukan uji coba terbatas terhadap perangkat pembelajaran yang dikembangkan, peneliti melakukan uji kemampuan awal siswa (pretest) untuk melihat sejauhmana pemahaman siswa terhadap materi pelajaran yang akan dipelajari. Dari hasil pretest yang diberikan, diperoleh rata-rata nilai pretest yaitu 33,79. Selanjutnya, dilakukan uji coba terbatas untuk melihat sejauhmana peningkatan pemahaman siswa terhadap konsep yang akan dipelajari dengan menggunakan perangkat pembelajaran yang dikembangkan. Uji coba terbatas dilakukan pada satu kelas di SMAN 13 Padang, yaitu kelas $\mathrm{X}_{3}$ dengan materi kalor untuk lima kali pertemuan. Setelah pembelajaran untuk materi kalor selesai dengan menggunakan perangkat pembelajaran, dilakukan tes akhir (postest) untuk melihat sejauh mana peningkatan pemahaman konsep siswa. 
Berdasarkan data hasil pretest dan posttest diperoleh nilai rata-rata posttest siswa adalah 72,64. Bila dibandingkan dengan nilai pretest, yang mana materi belum diajarkan terlihat tidak satupun nilai siswa yang tuntas atau diatas KKM, maka setelah diberikan perangkat pembelajaran terlihat bahwa terdapat peningkatan hasil belajar siswa pada ranah kognitif dan siswa sudah menguasai konsep-konsep yang telah diajarkan. Jika dipersentasekan, jumlah siswa yang bernilai sama atau lebih di atas KKM pada tes akhir (postest) adalah 78,5\% atau sebanyak 22 orang siswa dari 28 orang.

Begitu juga pada ranah afektif dan psikomotor. Dengan belajar berkelompok, siswa semakin termotivasi, kreatif, partisipasi aktif, mengemukakan pendapat, terbiasa mandiri dan memecahkan masalah. Nilai siswa untuk ketiga ranah dapat dilihat pada Tabel 12.

Tabel 12 Nilai rata-rata siswa

\begin{tabular}{|c|c|c|c|c|c|c|c|c|c|}
\hline Siswa & Ranah K & nitif & $\underset{\pi}{\frac{\pi}{\pi}} \underset{\pi}{\pi}$ & Ranah A & ktif & $\underset{\pi}{\frac{\pi}{\pi}} \underset{\pi}{\pi}$ & $\begin{array}{l}\text { Ranah } \\
\text { Psikomotor }\end{array}$ & & 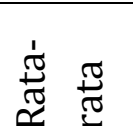 \\
\hline $\begin{array}{l}\text { Siswa } \\
\mathrm{X}_{3}\end{array}$ & 68,27 & 74,12 & 71,20 & 67,97 & 67,46 & 67,72 & 71,64 & 77,53 & 74,59 \\
\hline
\end{tabular}

Dari tabel 11, terlihat bahwa nilai ratarata siswa $X_{3}$ pada ranah kognitif 71,20 . Nilai rata-rata pada ranah afektif adalah 67,72 . Sedangkan nilai rata-rata pada ranah psikomotor adalah 74,59. Dari ketiga ranah yang dinilai, ternyata ranah psikomotor memperoleh nilai rata-rata lebih tinggi dari ranah lainnya. Dapat disimpulkan bahwa penggunaan perangkat pembelajaran tipe think-pair-share selama pembelajaran berlangsung dapat meningkatkan kompetensi fisika siswa karena terlihat dari motivasi, keaktifan, partisipasi, kinerja dan keterampilan siswa selama kegiatan pembelajaran.

\section{Pembahasan}

Adapun perangkat yang dikembangkan yaitu RPP, diktat ajar, silabus, LKS dan penilaian yang berbasis teknik Think-PairShare menggunakan model pengembangan 4-D. Dalam perancangan sebuah perangkat perlu dilakukan terlebih dahulu analisis terhadap kurikulum dan konsep yang diajarkan serta kebutuhan siswa. Setelah dilakukan analisis awal (tahap pendefenisian), barulah dirancang perangkat pembelajaran (tahap perancangan). Melalui proses berulangulang, diperoleh perangkat bersifat valid dan dinyatakan layak (tahap pengembangan). Pengembangan validasi perangkat ditekankan pada validasi isi, validasi bahasa dan validasi konstruk sehingga indikator penilaian terpenuhi dan memenuhi syarat-syarat penyusunan perangkat pembelajaran.

Hasil penvalidan validator menunjukkan bahwa untuk semua perangkat dinyatakan valid. Setelah perangkat valid, kemudian diuji kepraktisan dan keefektifannya. Pemanfaatan perangkat oleh guru saat belajar berguna untuk melihat kepraktisan, Diakhir pembelajaran, guru serta siswa dimintai mengisi setiap angket kepraktisan dari perangkat yang digunakan. Angket hasil penilaian guru menyebutkan bahwa perangkat yang dibuat peneliti sangat praktis digunakan saat belajar. Keefektifan dari perangkat berteknik sthink pair share yang digunakan dapat dari hasil rata-rata nilai siswa afektif dan kognitif maupun 
psikomotor setelah menggunakan perangkat yang dikembangkan, terlihat siswa memiliki motivasi, aktif, berpartisipasi, kreatif dan mandiri menyelesaiakn semua persoalan sehingga kompetensi siswa muncul secara optimal.

Lie (2002) mengemukakan bahwa "keunggulan kelompok berpasangan dapat meningkatkan partisipasi belajar serta interaksi dan komunikasi menjadi mudah". dari sini membuktikan penggunaan dari pengembangan sebuah perangkat berteknik Think-Pair-Share memberi peningkatan hasil secara keseluruhan pada proses pembelajaran. Terbukti efektif terhadap tujuan penelitian yaitu mampu meningkatkan kompetensi fisika siswa.

Produk disebut efektif bila memberikan hasil memuaskan sejalan dengan harapan pengembang (Asikin 2004). Perangkat ini dinyatakan sudah tervalidasi, mempunyai kepraktisan dan efektivitas yang baik sesuai dengan langkah model 4-D. Selain itu, pengembangan perangkat dengan penilaian dengan basis kelas mampu meningkatkan kompetensi fisika siswa baik di aspek afektif dan kognitif maupun psikomotor.

\section{KESIMPULAN DAN IMPLIKASI}

\section{Kesimpulan}

Perangkat suatu pembelajaran dengan basis teknik Think-Pair-Share berupa RPP, diktat belajar, LKS, silabus dan asesmen pada materi kalor sudah tervalidasi, mempunyai kepraktisan dan dinyatakan efektif. Perangkat sebuah pembelajaran pada materi fisika berbasis teknik Think-PairShare yang dikembangkan telah layak untuk mengukur yang seharusnya diukur menurut tujuan yangdirumuskan. Selama penelitian ada beberapa halangan selama penelitian antaranya waktu yang kurang termanage saat pembelajaran sehingga persentasi kelompok kurang maksimal.

Selain itu, pembelajaran masih dirasa belum optimal karena keterbatasan alat maupun bahan praktikum sehingga digunakan alat dari bahan yang dibawa siswa dari rumah. Namun secara keseluruhan, pembelajaran berjalan baik. Penggunaan perangkat ini memberi dampak pada peningkatan keseluruhan hasil belajar, sangat efektif terhadap pembelajaran sehingga kompetensi fisika siswa meningkat.

\section{Implikasi}

Perangkat pembelajaran fisika bertipe think-pair-share yang telah valid, praktis dan efektif dapat dijadikan sebagai salah satu inovasi dalam melaksanakan pembelajaran fisika di kelas. Perangkat ini sangat efektif dalam menimbulkan motivasi siswa, kreativitas, partisipasi dan membiasakan siswa memecahkan masalah secara mandiri serta tercipta suasana belajar yang menyenangkan sehingga kompetensi fisika siswa muncul secara optimal. Pengembangan dapat dilakukan oleh guru atau dikembangkan oleh pihak sekolah.

Agar pengembangan perangkat fisika bertipe think-pair-share memperoleh hasil yang maksimal, sekolah harus melengkapi sarana dan prasarana pembelajaran fisika seperti labor fisika beserta alat dan bahan pratikum. Namun yang perlu diperhatikan, kevalidan dan kepraktisan serta keefektifan perangkat ini tidak boleh diabaikan, karena faktor ini sangat menentukan kualitas perangkat pembelajaran yang dikembangkan.

\section{DAFTAR PUSTAKA}

Depdikbud. 2008. Kamus besar bahasa Indonesia. Balai Pustaka, Jakarta. 
Depdiknas. 2004. Pedoman khusus Lufri. 2006. Strategi pembelajaran pengembangan silabus dan penilaian biologi, teori, praktik, dan penelitian mata pelajaran fisika. Direktorat Jendral Pendidikan Dasar dan Pendidikan Menengah Umum, Jakarta.

Depdiknas. 2006. Penilaian berbasis kelas. Depdiknas, Jakarta.

Depdiknas. 2008. Perangkat pembelajaran ktsp SMA. Depdiknas, Jakarta.

Ibrahim M, dkk. 2000. Pembelajaran kooperatif. Unesa, Surabaya.

Lie A. 2002. Cooperative learning. Grasindo, Jakarta. buku ajar. UNP Press, Padang.

Suyitno A. 2006. Petunjuk praktis penelitian tindakan kelas untuk menyusun skripsi. Universitas negeri Semarang, Semarang.

Trianto. 2009. Mo0del pembelajaran terpadu dalam teori dan praktek. Prestasi Pustaka Publisher, Jakarta. 